\title{
Marine Bioactive Compounds against Aspergillus fumigatus: Challenges and Future Prospects
}

\author{
Chukwuemeka Samson Ahamefule ${ }^{1,2,3}$, Blessing C. Ezeuduji ${ }^{4}$, James C. Ogbonna ${ }^{3}$, \\ Anene N. Moneke ${ }^{3}$, Anthony C. Ike ${ }^{3}\left(\mathbb{D}\right.$, Bin Wang ${ }^{1,5}$, Cheng Jin 1,2,*(D) and Wenxia Fang $1,5, *$ (D) \\ 1 National Engineering Research Center for Non-Food Biorefinery, Guangxi Academy of Sciences, \\ Nanning 530007, China; chukwuemeka.ahamefule.pg79618@unn.edu.ng (C.S.A.); bwang@gxas.cn (B.W.) \\ 2 College of Life Science and Technology, Guangxi University, Nanning 530005, China \\ 3 Department of Microbiology, University of Nigeria, Nsukka 410001, Nigeria; \\ james.ogbonna@unn.edu.ng (J.C.O.); anene.moneke@unn.edu.ng (A.N.M.); \\ anthonyc.ike@unn.edu.ng (A.C.I.) \\ 4 Department of Microbiology, University of Jos, Jos 930001, Nigeria; bezeuduji@gmail.com \\ 5 State Key Laboratory of Non-food Biomass and Enzyme Technology, Guangxi Academy of Sciences, \\ Nanning 530007, China \\ * Correspondence: jinc@im.ac.cn (C.J.); wfang@gxas.cn (W.F.)
}

Received: 9 October 2020; Accepted: 12 November 2020; Published: 16 November 2020 updates

\begin{abstract}
With the mortality rate of invasive aspergillosis caused by Aspergillus fumigatus reaching almost $100 \%$ among some groups of patients, and with the rapidly increasing resistance of A. fumigatus to available antifungal drugs, new antifungal agents have never been more desirable than now. Numerous bioactive compounds were isolated and characterized from marine resources. However, only a few exhibited a potent activity against $A$. fumigatus when compared to the multitude that did against some other pathogens. Here, we review the marine bioactive compounds that display a bioactivity against $A$. fumigatus. The challenges hampering the discovery of antifungal agents from this rich habitat are also critically analyzed. Further, we propose strategies that could speed up an efficient discovery and broaden the dimensions of screening in order to obtain promising in vivo antifungal agents with new modes of action.
\end{abstract}

Keywords: marine resources; Aspergillus fumigatus; bioactive compounds; screening model; fungi

\section{Introduction}

Aspergillus fumigatus is a saprophytic mold commonly found in the environment, with spores that are very light and easily disseminated [1]. It is also a potentially dangerous opportunistic pathogen that is reported as being the number one causative mold for mycoses, especially in immunocompromised patients [2]. Invasive aspergillosis (IA) caused by A. fumigatus is a severe systemic infection with high mortality and morbidity rates. IA has an annual global incidence of over 200,000, and the mortality rate could reach almost $100 \%$ among certain categories of patients if not properly treated [2-4].

With the already existing challenge of having only a limited repertoire of antifungal drugs for the treatment of aspergilloses, the continuous rise of drug resistance in A. fumigatus strains [5-7] further aggravates this challenge. Reports of $A$. fumigatus developing a resistance, in both clinical $[8,9]$ and environmental $[10,11]$ isolates, to antifungal drugs such as amphotericin $B$ [12], azole-class drugs [13,14] and echinocandins [5,15], as well as developing a multidrug resistance [16], are increasing annually.

In the UK for example, Public Health England reported over a five-fold increase in A. fumigatus isolates that showed resistance to itraconazole (Minimum Inhibitory Concentration (MIC) $\geq 2.0 \mu \mathrm{g} / \mathrm{mL}$ ) 
from $2012(1.4 \%)$ to $2016(8.5 \%)$, whereas $4.7 \%$ and $6.9 \%$ increased resistance to voriconazole (MIC $\geq 2.0 \mu \mathrm{g} / \mathrm{mL}$ ) and posaconazole (MIC $\geq 0.25 \mu \mathrm{g} / \mathrm{mL}$ ), respectively [17]. A study from Brazil by Reichert-Lima [18] showed one of the highest resistances (27\%) of A. fumigatus to amphotericin B (MIC $\geq 2.0 \mu \mathrm{g} / \mathrm{mL}$ ).

Due to its peculiar environment and rich biodiversity, the marine resource is a treasure box for isolating novel bioactive compounds. Over the years, antibacterial [19-21], antifungal [22,23], antiviral [24-26], anthelminths [27,28], antiprotozoan [29-31], antitumor [32,33], anticancer [34-36], anti-inflammatory [37,38], antioxidant [39,40], antiaging [41,42] and antidiabetics [43-45] compounds have been isolated from different marine organisms.

Among the reported antifungals isolated from the marine environment, only a few have been found to be effective against the recalcitrant fungus, A. fumigatus. Considering the threat of this important pathogen, in this review we have compiled and discussed bioactive compounds, isolated from the marine environment over the last two decades, which displayed an activity against $A$. fumigatus. We have also discussed the challenges restricting the discovery and isolation of effective agents against A. fumigatus from the marine environment. We have further proffered enhanced methods and multiple strategies that may improve the future discovery of marine antifungal agents.

\section{A. fumigatus and Aspergillosis}

Yu et al. [46] defined aspergillosis as a clinical infection caused by the genus Aspergillus, which can lead to allergic, superficial, saprophytic or invasive diseases. Cases of aspergillosis have constantly been on the increase since it was first reported over a century ago by Bennett [47]. Although aspergillosis is popularly associated with immunocompromised patients, over the years it has rapidly evolved in epidemiology, with increasingly new groups of patients at risk, even among the supposedly non-immunocompromised individuals [1,48].

Cases of varying kinds of aspergillosis have been reported among non-immunocompromised patients for years now, such as craniocerebral aspergillosis of sino-nasal origin [49,50], chronic invasive sinus aspergillosis [51], orbital aspergillosis [52-54], fatal invasive aspergillosis [55], intracranial aspergillosis [56], central nervous system aspergillosis [57], pulmonary aspergillosis [58,59], and adrenal and hepatic aspergillosis [60].

A. fumigatus has been reported as the most frequent etiological mold for invasive aspergillosis over the past two decades [61,62]. Unfortunately, the rapid evolution of drug resistant strains of this fungus complicates aspergillosis cases and limits clinical treatment by available antifungal drugs $[6,8,63]$. This has driven global searches for promising and potent new agents against $A$. fumigatus. Notwithstanding the fact that no new drug class has been discovered, some promising effective compounds have, however, been isolated and characterized from the marine environment.

\section{Bioactive Compounds from Marine Organisms against $A$. fumigatus}

A number of effective bioactive compounds against A. fumigatus have been isolated from marine organisms over the last two decades. Some of these compounds have been characterized and demonstrated as giving an appreciable potency against A. fumigatus. Other compounds, on the other hand, have been reported to have a weaker activity. These active compounds were isolated from different marine organisms, including bacteria [64,65], most of which were actinomycetes [66-68], fungi [69,70], algae and seaweed [71-74], sponges [75-78], and sea cucumbers [79-81].

\subsection{A. fumigatus Effective Compounds from Marine Bacteria}

Compounds with antifungal activity against $A$. fumigatus have been isolated from marine bacteria such as Bacillus $[65,82]$, and more frequently from the unicellular filamentous bacteria actinomycetes [83-85]. Certain compounds, such as the caniferolides [85], have been characterized and shown to have a good activity against $A$. fumigatus (Table 1; Figure 1). Some other compounds, such as 30-oxo-28-N-methylikarugamycin, isolated from Streptomyces zhaozhouensis, only showed a 
very weak activity against $A$. fumigatus, with MICs of $>64 \mu \mathrm{g} / \mathrm{mL}$ [83]. On the other hand, extracts from some streptomycetes [86,87], and other bacteria like Micrococcus sp., Flavobacterium sp. and Streptomyces sp. [64], have also been demonstrated as possessing very effective activities against A. fumigatus (Table 2). More interestingly, some of these extracts also showed promising activities against $A$. fumigatus strains with multidrug resistance (MDR) (Table 2).

Table 1. Compounds from marine Streptomyces and other bacteria with antifungal activity against A. fumigatus.

\begin{tabular}{|c|c|c|c|c|}
\hline Compound & $\begin{array}{c}\text { Description/Source } \\
\text { of Compound }\end{array}$ & Compound Class & $\begin{array}{c}\text { Activity } \\
\text { (MIC } \mu \mathrm{g} / \mathrm{mL})\end{array}$ & Reference \\
\hline Isoikarugamycin & $\begin{array}{c}\text { Ethyl acetate extract from } \\
\text { Streptomyces zhaozhouensis } \\
\text { CA-185989 broth }\end{array}$ & $\begin{array}{l}\text { polycyclic tetramic } \\
\text { acid macrolactams }\end{array}$ & $4-8$ & [83] \\
\hline 28-N-methylikaguramycin & $\begin{array}{c}\text { Ethyl acetate extract from } \\
\text { Streptomyces zhaozhouensis } \\
\text { CA-185989 broth }\end{array}$ & $\begin{array}{l}\text { polycyclic tetramic } \\
\text { acid macrolactams }\end{array}$ & $4-8$ & [83] \\
\hline Ikarugamycin & $\begin{array}{c}\text { Ethyl acetate extract from } \\
\text { Streptomyces zhaozhouensis } \\
\text { CA-185989 broth }\end{array}$ & $\begin{array}{l}\text { polycyclic tetramic } \\
\text { acid macrolactams }\end{array}$ & $4-8$ & {$[83]$} \\
\hline Caniferolides A\&B & $\begin{array}{c}\text { Ethyl acetate extract from } \\
\text { Streptomyces caniferus } \\
\text { CA-271066. }\end{array}$ & polyol macrolides & $2-4$ & [85] \\
\hline $4,4^{\prime}$-oxybis(3-phenylpropionic acid) & $\begin{array}{c}\text { Ethyl acetate concentrates of } \\
\text { methanolic extract from } \\
\text { Bacillus licheniformis }\end{array}$ & oxyneolignan & $7-10 \mathrm{~mm} *$ & [65] \\
\hline
\end{tabular}


a

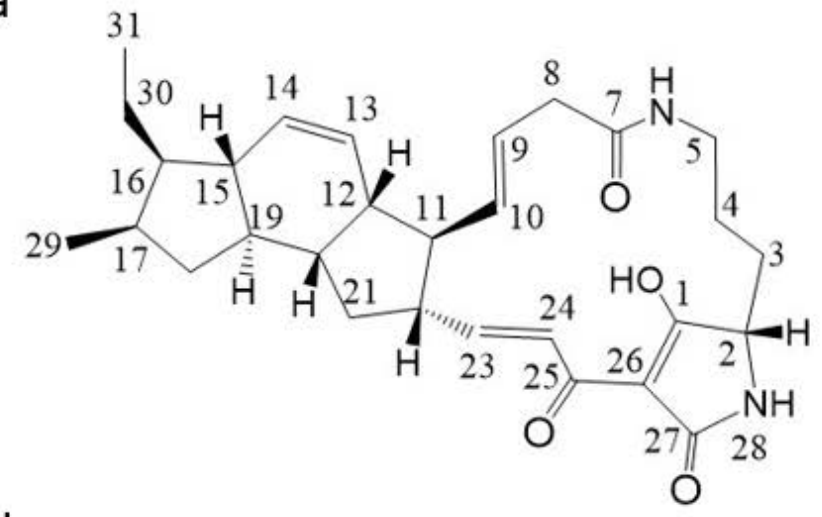

b

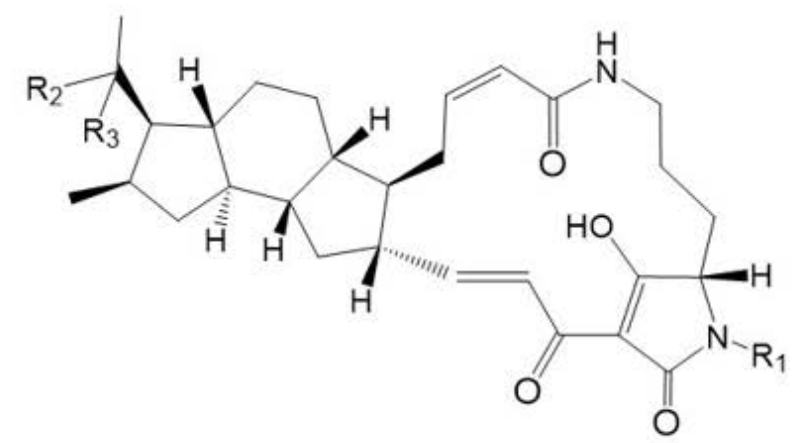

d

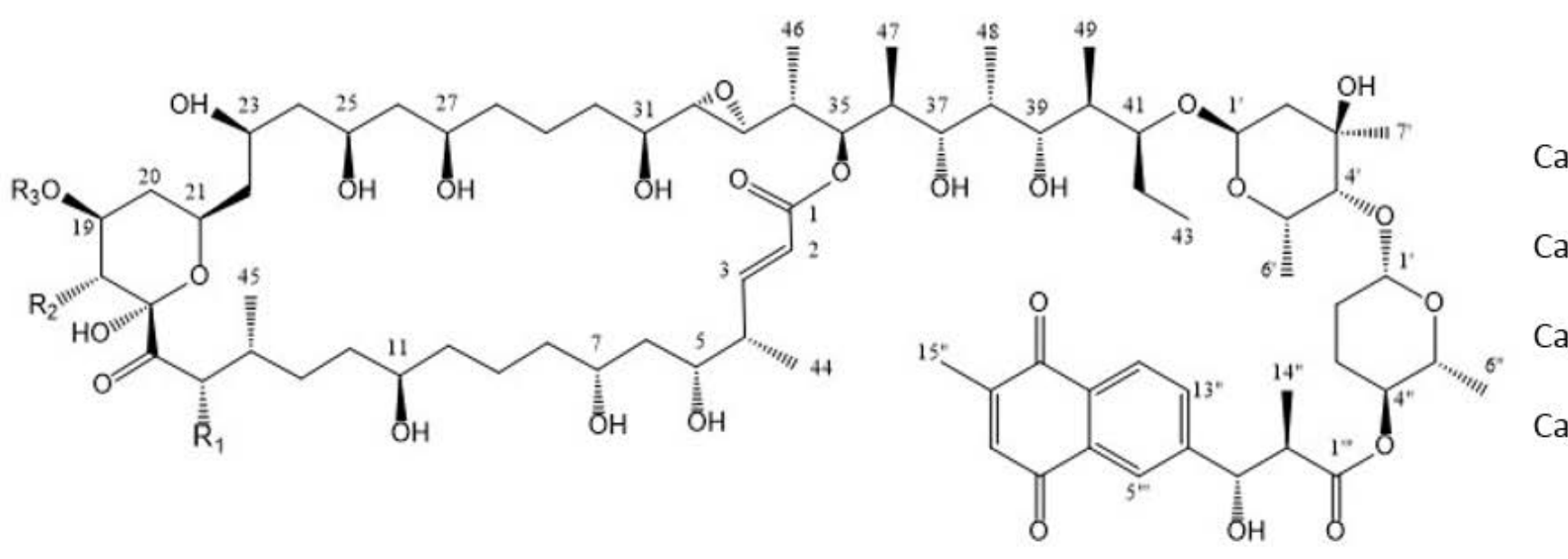

Figure 1. Chemical structures of compounds from marine bacteria with antifungal activity against A. fumigatus. (a) Isoikarugamycin, (b) 28-N-methylikaguramycin, (c) 4,4'-oxybis [3-phenylpropionic acid] and (d) Caniferolide A-D. 
Table 2. Antifungal activity of extracts from marine actinomycetes and other bacteria against $A$. fumigatus or MDR A. fumigatus.

\begin{tabular}{|c|c|c|c|}
\hline Isolate & Description & Activity (MIC $\mu \mathrm{g} / \mathrm{mL}$ ) & Reference \\
\hline Streptomyces sp. VITSDK36 & Ethyl acetate extract & 1.32 & [87] \\
\hline Streptomyces sp. VITSDK37 & Ethyl acetate extract & 0.74 & [87] \\
\hline Streptomyces sp. VITSDK38 & Ethyl acetate extract & 1.64 & [87] \\
\hline Streptomyces sp. VITSDK39 & Ethyl acetate extract & 1.78 & [87] \\
\hline Streptomyces sp. VITSDK41 & Ethyl acetate extract & 2.68 & [87] \\
\hline Streptomyces sp. VITSDK42 & Ethyl acetate extract & 1.58 & [87] \\
\hline Actinopolyspora sp. VITSDK43 & Ethyl acetate extract & 1.58 & [87] \\
\hline Actinopolyspora sp. VITSDK44 & Ethyl acetate extract & 2.54 & [87] \\
\hline Micromonospora sp. VITSDK46 & Ethyl acetate extract & 1.40 & [87] \\
\hline Sachharopolyspora sp. VITSDK47 & Ethyl acetate extract & 0.90 & [87] \\
\hline Streptomyces VITSVK5 spp. & Ethyl acetate extract & 0.5 & [86] \\
\hline Micrococcus sp. RRL-3 & Methanol extract & 0.5 & [64] \\
\hline Flavobacterium sp. RRL-10 & Methanol extract & 5.5 & [64] \\
\hline Pseudomonas sp. RRL-12 & Methanol extract & 0.9 & [64] \\
\hline Streptomyces sp. RRL-13 & Methanol extract & 0.7 & [64] \\
\hline Flavobacterium sp. RRL-20 & Methanol extract & 4.3 & [64] \\
\hline Flavobacterium sp. RRL-32 & Methanol extract & 0.9 & [64] \\
\hline Micrococcus sp. RRL-37 & Methanol extract & 0.8 & [64] \\
\hline Bacillus sp. RRL-38 & Methanol extract & 2.0 & [64] \\
\hline Flavobacterium sp. RRL-41 & Methanol extract & 1.3 & [64] \\
\hline Flavobacterium sp. RRL-54 & Methanol extract & 0.5 & [64] \\
\hline Alcaligenes sp. RRL-56 & Methanol extract & 0.3 & [64] \\
\hline Bacillus sp. RRL-57 & Methanol extract & 2.5 & [64] \\
\hline Streptomyces VITSVK5 spp. & Ethyl acetate extract against MDR9 & $4^{*}$ & [86] \\
\hline Streptomyces VITSVK5 spp. & Ethyl acetate extract against MDR10 & $0.25 *$ & [86] \\
\hline Streptomyces VITSVK5 spp. & Ethyl acetate extract against MDR11 & $2 *$ & [86] \\
\hline
\end{tabular}

\subsection{A. fumigatus Effective Compounds from Marine Sponges}

Marine sponges, such as Theonella swinhoei, Siliquariaspongia japonica and Microscleroderma herdmani, are other categories of interesting marine organisms demonstrated to produce effective antifungal compounds against $A$. fumigatus. Compounds such as Aurantosides E, A, B and Microsclerodermin B are the best antifungal bioactive compounds against $A$. fumigatus, with MICs of 0.04, 0.16, 0.16 and $0.6 \mu \mathrm{g} / \mathrm{mL}$, respectively [77,88] (Table 3; Figure 2). Moreover, other Microsclerodermins (A, J and K) and Swinhoeiamide A also exhibit a good antifungal activity against A. fumigatus, with MICs ranging between 1 to $10 \mu \mathrm{g} / \mathrm{mL}[77,89]$ (Table 3). 
a

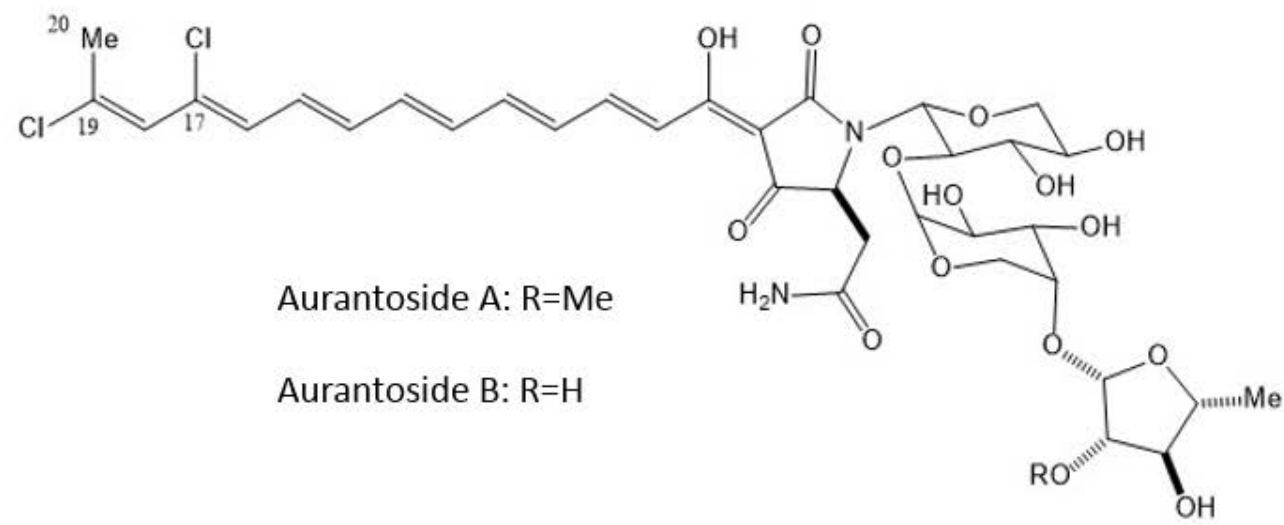

b

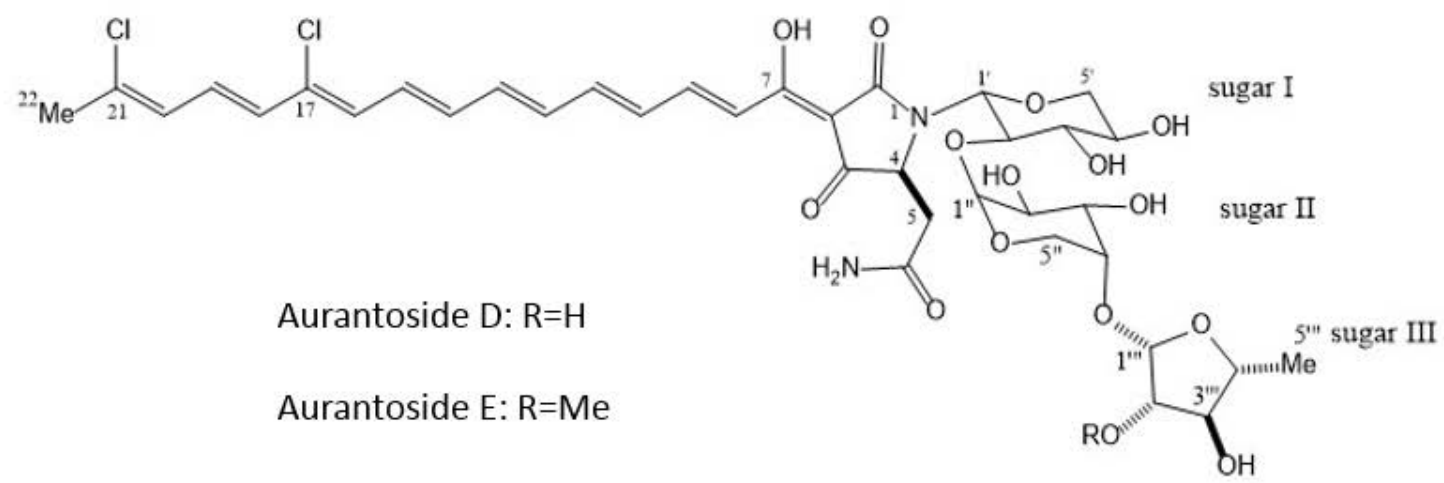

Figure 2. Chemical structures of compounds from marine sponges with antifungal activities against A. fumigatus. (a) Aurantosides A \& B, (b) Aurantosides D \& E, and (c) Microsclerodermin A \& B. 
Table 3. Effective compounds against $A$. fumigatus from marine sponges.

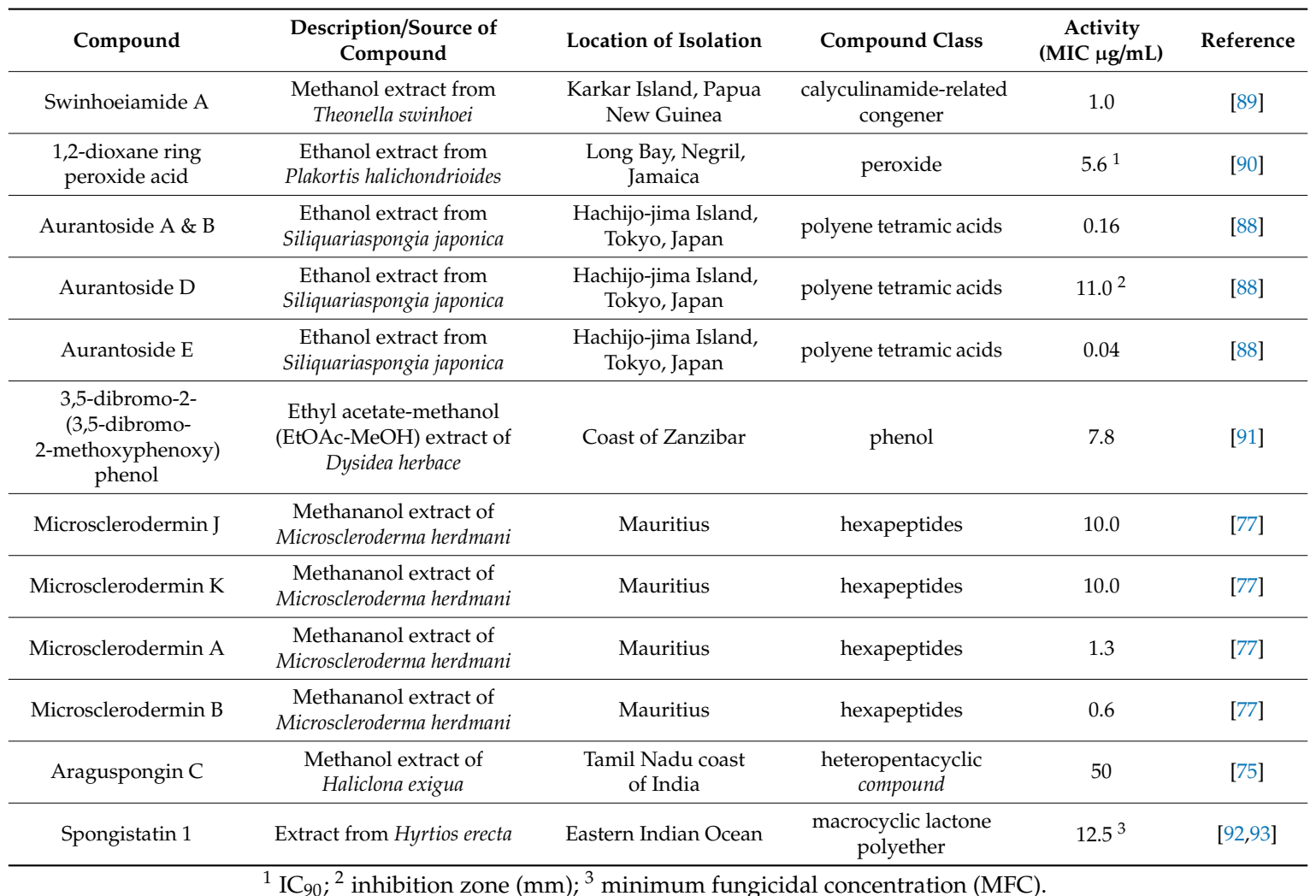

\subsection{A. fumigatus Effective Compounds from Marine Algae}

Both compounds and extracts from several marine algae have been demonstrated to exhibit antifungal activities against $A$. fumigatus. The bromophenol compound 2,20,3,30-tetrabromo-4,40,5,50-tetrahydroxydiphenylmethane is one of the most potent compounds from marine algae, with a potent activity against $A$. fumigatus (with an MIC of $0.78 \mu \mathrm{g} / \mathrm{mL}$ ) [94] (Table 4; Figure 3). Furthermore, ethanol extracts from Laurencia majuscula and Padina pavonica displayed an effective activity against $A$. fumigatus at low MICs of 1.95 and $0.95 \mu \mathrm{g} / \mathrm{mL}$, respectively [71] (Table 4).

Table 4. Effective antifungal compounds/extracts against $A$. fumigatus from marine algae.

\begin{tabular}{cccc}
\hline Compound/Isolate & Description/Source of Compound & Activity (MIC $\mathrm{\mu g} / \mathrm{mL})$ & Reference \\
\hline $\begin{array}{c}\text { 2,20,3,30-tetrabromo-4,40,5,50- } \\
\text { tetrahydroxydiphenylmethane }\end{array}$ & Compounds from Odonthalia corymbifera & 0.78 & [94] \\
\hline $\begin{array}{c}\text { 3-bromo-4-(2,3-dibromo- } \\
\text { 4,5-dihydroxybenzyl)-5- } \\
\text { methoxymethylpyrocatechol }\end{array}$ & Compounds from Odonthalia corymbifera & 25 & [94] \\
\hline $\begin{array}{c}(E)-2-\{(E) \text { tridec-2-en-2-yl\} } \\
\text { heptadec-2-enal }\end{array}$ & $\begin{array}{c}\text { Chloroform/methanol extract of } \\
\text { Laurencia papillosa }\end{array}$ & 200 & [95] \\
\hline Extract & Ethanol extract from Laurencia catarinensis & 3.90 & [71] \\
\hline Extract & Ethanol extract from Laurencia majuscula & 1.95 & [71] \\
\hline Extract & Ethanol extract from Padina pavonica & 0.98 & [71] \\
\hline
\end{tabular}


<smiles>NCCc1cc(Br)c(O)c(Br)c1</smiles>

b<smiles>Oc1cc(Cc2cc(O)c(O)c(Br)c2Br)c(Br)c(Br)c1O</smiles>

Figure 3. Bromophenol compounds from marine algae with antifungal activities against A. fumigatus. (a) 2,20,3,30-tetrabromo-4,40,5,50 tetrahydroxydiphenylmethane and (b) 3-bromo-4(2,3-dibromo-4,5-dihydroxybenzyl)-5 methoxymethylpyrocatechol.

\subsection{A. fumigatus Effective Compounds from Sea Cucumbers}

Several triterpene glycosides (Figure 4) with good antifungal activities against $A$. fumigatus have been isolated and characterized from sea cucumbers such as Holothuria scabra, Actinopyga lecanora, several species of Bohadschia, etc. [80,81,96,97]. Among the best bioactive compounds isolated from these marine echinoderms, potent activities with an $\mathrm{MIC}_{80}$ ranging from 1.0 to $4.0 \mu \mathrm{g} / \mathrm{mL}$ have been recorded in in vitro screenings (Table 5). Triterpene glycosides therefore present very good prospects for future antifungal drug development.

Besides characterized compounds, both crude and partially purified extracts from different sea cucumbers have also been demonstrated to exhibit varying levels of antifungal activities against A. fumigatus. Ismail et al. [79] reported that crude and semipurified extracts from both aqueous body fluid extracts and methanolic wall extracts from Holothuria polii displayed varying activities against A. fumigatus in a concentration-dependent manner. Methanolic body-wall crude extracts showed better activities than those of aqueous body fluid. However, there was no difference in activities among the extracts after purification. Similarly, Adibpour et al. [98] also recorded an antifungal activity against $A$. fumigatus from Holothuria leucospilota body-wall and coelomic fluid extracts but none from its cuvierian organs' extracts. 


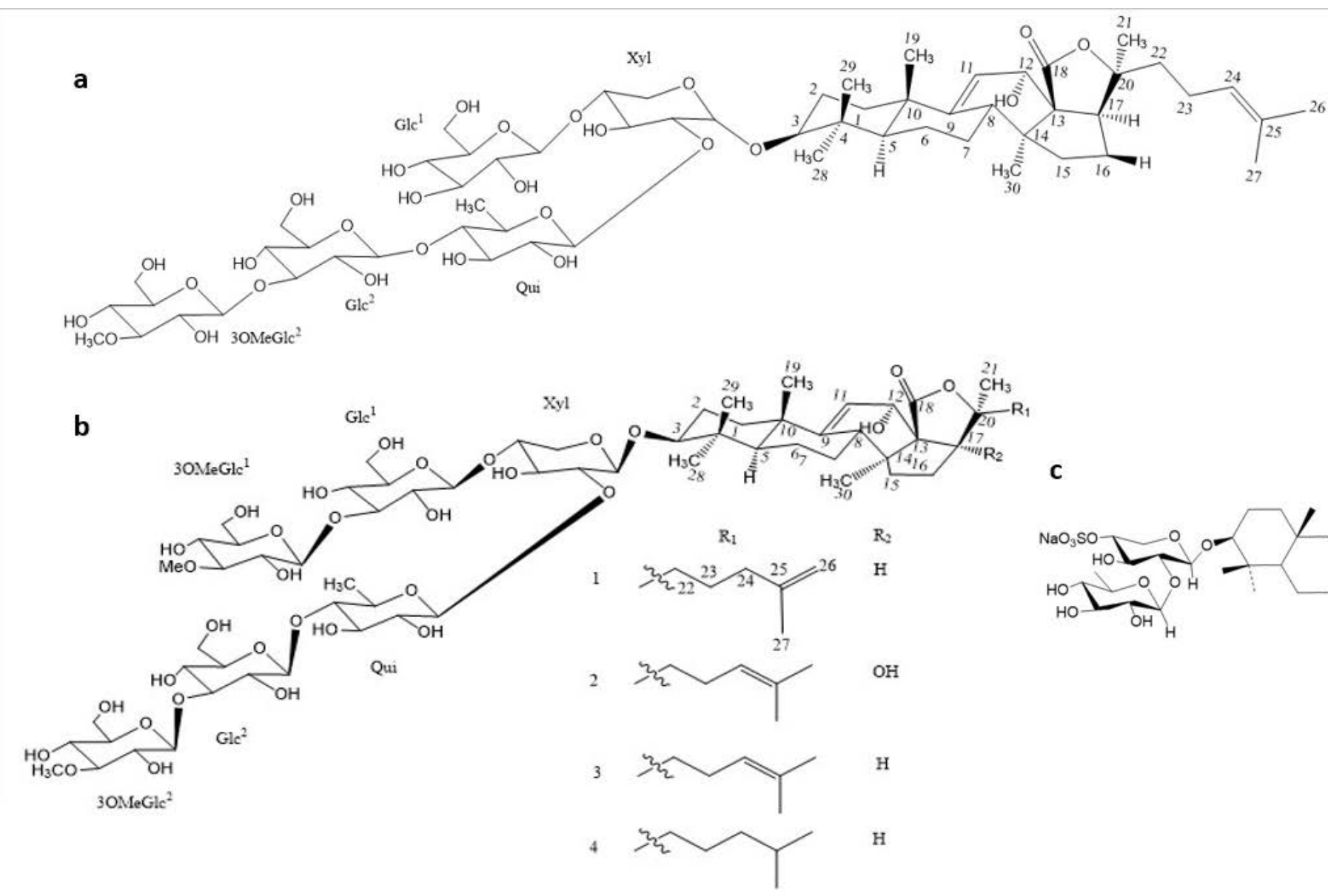

Figure 4. Chemical structure of compounds from sea cucumbers with effective antifungal activities against $A$. fumigatus. (a) Impatienside B, (b) Marmoratoside A (1); $17 \alpha$-hydroxy impatienside (2); Impatienside A (3); \& Bivittoside D (4), and (c) Holothurin B.

Table 5. Characterized compounds against A. fumigatus from sea cucumbers.

\begin{tabular}{|c|c|c|c|c|}
\hline Compounds & Sea Cucumber & Compound Class & $\begin{array}{c}\text { Activity } \\
\text { (MIC } \mu \mathrm{g} / \mathrm{mL})\end{array}$ & Reference \\
\hline Scabraside A & Holothuria scabra & Triterpene glycosides & $2.0^{*}$ & [97] \\
\hline Echinoside A & Holothuria scabra & Triterpene glycosides & $1.0^{*}$ & [97] \\
\hline Holothurin $\mathrm{A}_{1}$ & Holothuria scabra & Triterpene glycosides & $8.0^{*}$ & [97] \\
\hline Holothurin B & Actinopyga lecanora & Triterpene glycosides & 3.12 & [82] \\
\hline $\begin{array}{l}\text { 3-O-b-D-xylopyranosyl- } \\
\text { 16b-acetoxyholost-7-ene }\end{array}$ & Actinopyga lecanora & Triterpene glycosides & 50.0 & [96] \\
\hline Holothurin A & Actinopyga lecanora & Triterpene glycosides & 50.0 & [96] \\
\hline Bivittoside-D & Bohadschia vitiensis Semper & Lanostane triterpenoid & 1.56 & [99] \\
\hline Marmoratoside A & Bohadschia marmorata Jaeger. & Triterpene glycosides & $2.81^{*}$ & [80] \\
\hline Marmoratoside B & Bohadschia marmorata Jaeger. & Triterpene glycosides & $44.44^{*}$ & [80] \\
\hline $17 \alpha$-hydroxy impatienside $\mathrm{A}$ & Bohadschia marmorata Jaeger. & Triterpene glycosides & $2.78^{*}$ & [80] \\
\hline Impatienside A & Bohadschia marmorata Jaeger. & Triterpene glycosides & $2.81^{*}$ & [80] \\
\hline Bivittoside D & Bohadschia marmorata Jaeger. & Triterpene glycosides & $2.80^{*}$ & [80] \\
\hline 25-acetoxy bivittoside $\mathrm{D}$ & Bohadschia marmorata Jaeger. & Triterpene glycosides & $43.13^{*}$ & [80] \\
\hline Arguside F & Holothuria (Microthele) axiloga & Holostan-type triterpene glycosides & $16.0 *$ & [81] \\
\hline Impatienside B & Holothuria (Microthele) axiloga & Holostan-type triterpene glycosides & $4.0^{*}$ & [81] \\
\hline Pervicoside D & Holothuria (Microthele) axiloga & Holostan-type triterpene glycosides & $64.0^{*}$ & [81] \\
\hline
\end{tabular}




\subsection{A. fumigatus Effective Compounds from Marine Fungi}

A few studies have reported bioactive compounds from marine fungi against pathogenic molds. With reference to A. fumigatus, to the best of our knowledge, only the marine fungus Phoma sp. produced a characterized bioactive compound, YM-202204, with an $\mathrm{IC}_{80}$ of $12.5 \mu \mathrm{g} / \mathrm{mL}$ against A. fumigatus [69]. We propose that most fungi do indeed produce necessary antagonism metabolites against their fellow fungi if "they feel threatened" or if there is competition. That is why we have proposed several enhanced pathways (e.g., the coculture approach) for isolating and screening bioactive compounds (Figures 5 and 6).

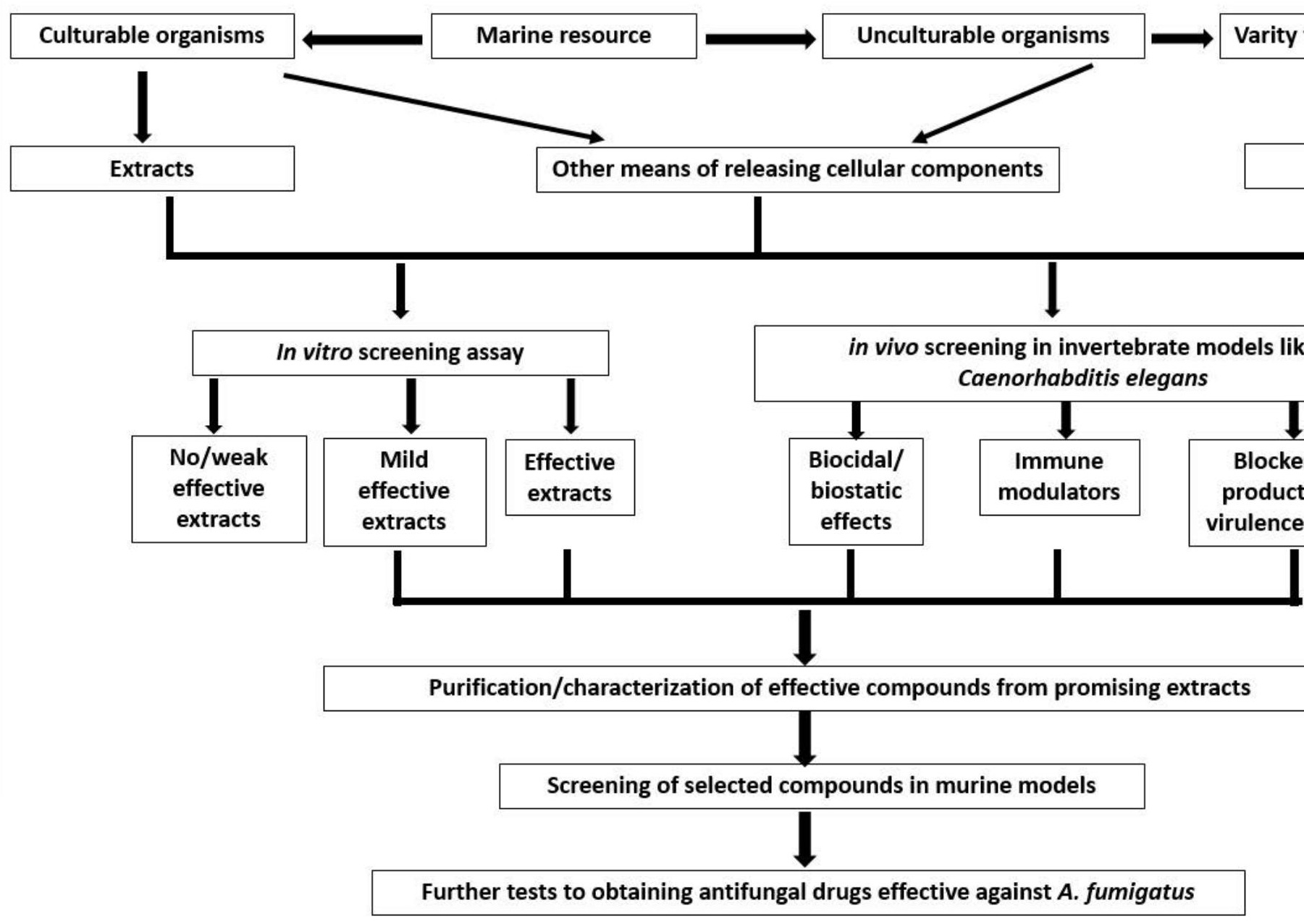

Figure 5. Flow chart of possible approaches to enhance the chances of discovering potent antifungal agents against $A$. fumigatus. 


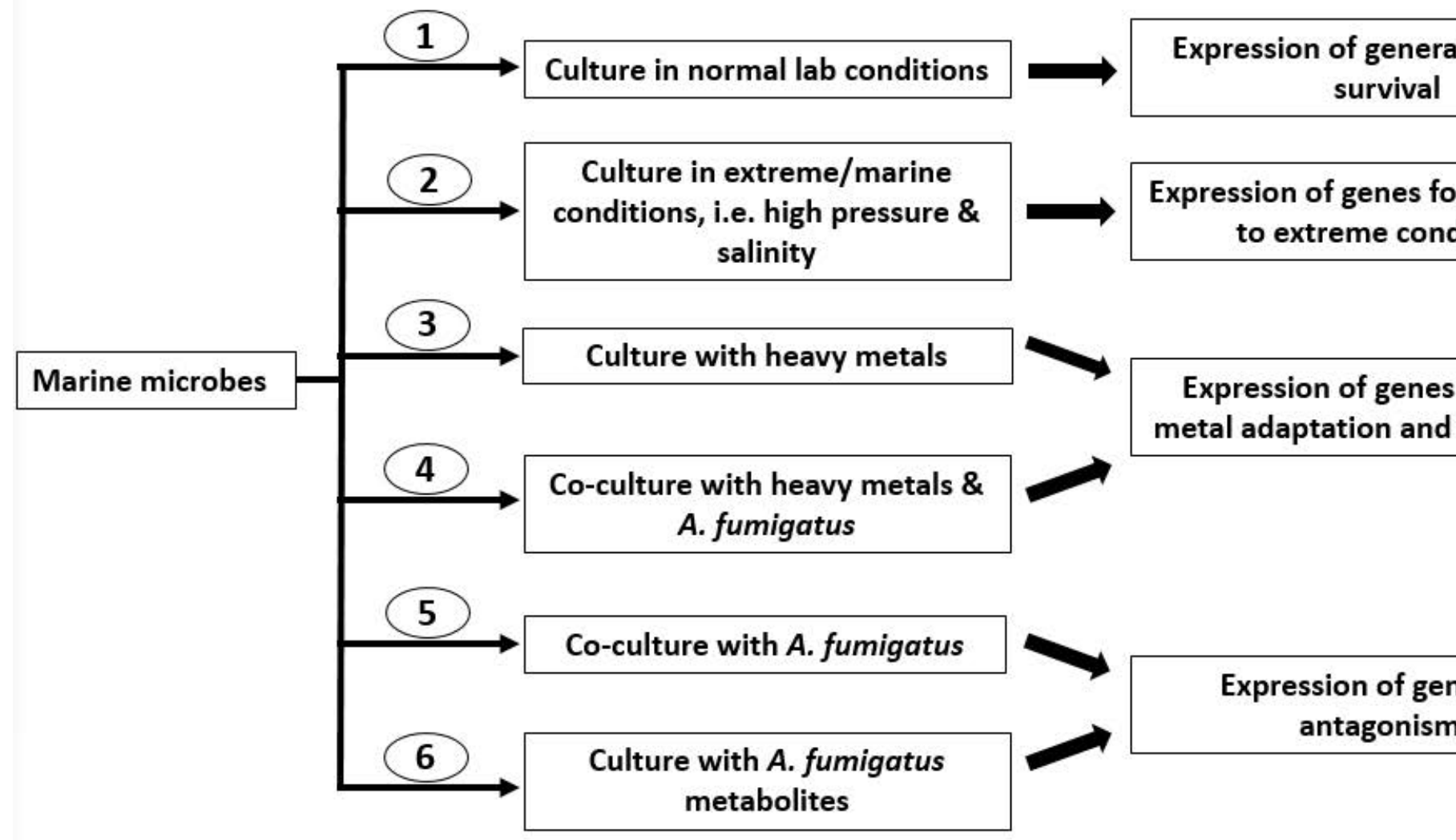

Figure 6. Suggested culture approaches to increase the discovery of antifungal bioactive compounds.

\section{Challenges and Future Prospects}

One of the biggest challenges facing the discovery of effective antifungal agents against A. fumigatus and other pathogenic microorganisms from a rich marine environment is the limitation on culturable organisms. It has been proven that the vast majority of microorganisms in nature cannot be isolated through the usual cultural techniques and are therefore labelled as unculturable microorganisms $[100,101]$, where marine microbes predominate. Therefore, obtaining these viable but unculturable marine microbes by using several methods, including molecular approaches [102] and simpler techniques such as a long incubation with low nutrition [101], will certainly open a new vista of opportunities for discovering new antimicrobial agents. This may consequently lead to obtaining and evaluating novel metabolites from those unisolated and uncharacterized microorganisms, increasing the possibility of discovering potent antimicrobials, including antifungal agents against $A$. fumigatus (Figure 5).

Furthermore, the techniques and methods currently adopted in the isolation and screening of these bioactive compounds require upgrading in order to increase the chances of identifying new broad spectrum antimicrobial agents. For example, mainly focusing on extracellular components from these marine microorganisms seriously limits the global progress in this search. Considering the fact that marine organisms are unique, with special cellular features and components to survive in extreme and peculiar environments, it will be desirable to isolate and test intracellular and membrane-bound polysaccharides, peptides and lipids [103,104].

Moreover, conducting an initial screening of these compounds with predominantly in vitro assays might just be another limitation in this search. It has previously been demonstrated that certain compounds with weak in vitro antimicrobial activities could still be quite effective in in vivo applications [105-108]. Such compounds could have alternative mechanisms of "conquering the pathogen(s) of interest" beyond biocidal/biostatic activities. Other mechanisms than just the usual 
growth inhibition of pathogens, such as the modulation of the host immune system or blocking the production of virulence factor(s), are enviable attributes of new compounds that can only be discovered with in vivo assays [107-110]. Therefore, in vivo screening assays are highly recommended to discover bioactive compounds with broader modes of action.

Using invertebrate models such as Caenorhabditis elegans for a high-throughput in vivo screening has numerous advantages, including the absence of an ethical license requirement, reduced cost, labor and resources, as well as the possibility to simultaneously determine the cytotoxity of bioactive compounds [105,110]. We have recently established a C. elegans-based A. fumigatus infection model [111], making the high-throughput evaluation of the efficacy of bioactive compounds possible. Furthermore, we also discovered that the in vivo efficacy of some antifungal agents was different from what was observed in in vitro screenings, as demonstrated by the different killing modes of amphotericin B and the azole drugs. These therefore provide confidence in high-throughput in vivo assays as the primary screening approach.

Based on the general numbers of bioactive compounds from marine microbes, there are multiple strategies for inducing the production of some essential bioactive metabolites that possess antifungal properties, such as coculturing marine microbes with stimulators (other microorganisms, pathogens/their metabolites) or exposing them to stress conditions. Heavy metal stress could induce the expression of genes that lead to the production of desired metabolites, some of which have also been discovered to possess antimicrobial properties [112-116]. The use of heavy metals in the culture media of certain marine organisms is necessary for inducing the production of some essential metabolites, which may have antifungal properties. Evaluating such antifungal potency on A. fumigatus would really help to broaden the future search and discovery of antimicrobial compounds.

We have therefore suggested cultural approaches in Figure 6 in order to broaden and hasten the search for antifungal agents against $A$. fumigatus. Six culture approaches, ranging from monocultures to cocultures under different conditions, are suggested to stimulate genes involved in the production of uncommon metabolites, thereby increasing the possibilities of finding novel bioactive compounds that may otherwise not be identified through conventional approaches.

\section{Conclusions}

The search for antifungal agents effective against $A$. fumigatus from the marine habitat has not been all that productive (compared to other similar leading opportunistic pathogens like Candida albicans) for years now. A change of strategy is therefore indispensable and urgent if we must win the raging menacing war against this mold pathogen. Adoption of alternative cultural methods and evaluation of compounds for other treatment mechanisms would help to broaden the horizon of this search and may as well just be the needed breakthrough that we are waiting for.

Author Contributions: C.S.A. and B.C.E. wrote the initial manuscript. J.C.O.; A.N.M., A.C.I., B.W., C.J. and W.F. revised the manuscript. W.F. supervised the manuscript. All authors have read and agreed to the published version of the manuscript.

Funding: This work was supported by National Natural Science Foundation of China $(31960032,32071279)$, Guangxi Natural Science Foundation (2018GXNSFAA138012, 2020GXNSFDA238008) and Research Start-up Funding of Guangxi Academy of Sciences (2017YJJ025) to W.F., Bagui Scholar Program Fund (2016A24) of Guangxi Zhuang Autonomous Region to C.J.

Conflicts of Interest: The authors declare no conflict of interest.

\section{References}

1. Latgé, J.P.; Chamilos, G. Aspergillus fumigatus and aspergillosis in 2019. Clin. Microbiol. Rev. 2019, 33, e00140-18. [CrossRef] [PubMed]

2. Geißel, B.; Loiko, V.; Klugherz, I.; Zhu, Z.; Wagener, N.; Kurzai, O.; van den Hondel, C.A.M.J.J.; Wagener, J. Azole-induced cell wall carbohydrate patches kill Aspergillus fumigatus. Nat. Commun. 2018, 9. [CrossRef] [PubMed] 
3. Darling, B.A.; Milder, E.A. Invasive aspergillosis. Pediatr. Rev. 2018, 39, 476-478. [CrossRef] [PubMed]

4. Linder, K.A.; McDonald, P.J.; Kauffman, C.A.; Revankar, S.G.; Chandrasekar, P.H.; Miceli, M.H. Invasive aspergillosis in patients following umbilical cord blood transplant. Bone Marrow Transpl. 2019, 54, 308-311. [CrossRef] [PubMed]

5. Jiménez-Ortigosa, C.; Aimanianda, C.; Muszkieta, L.; Mouyna, I.; Alsteens, D.; Pire, S.; Beau, R.; Krappmann, S.; Beauvais, A.; Dufrêne, Y.F.; et al. Chitin synthases with a myosin motor-like domain control the resistance of Aspergillus fumigatus to echinocandins. Antimicrob. Agents Chemother. 2012, 56, 6121-6131. [CrossRef]

6. Abdolrasouli, A.; Scourfield, A.; Rhodes, J.; Shah, A.; Elborn, J.S.; Fisher, M.C.; Schelenz, S.; Armstrong-James, D. High prevalence of triazole resistance in clinical Aspergillus fumigatus isolates in a spe-cialist cardio-thoracic centre. Int. J. Antimicrob. Agents 2018, 52, 637-642. [CrossRef]

7. Wirmann, L.; Ross, B.; Reimann, O.; Steinmann, J.; Rath, P.-M. Airborne Aspergillus fumigatus spore concentration during demolition of a building on a hospital area and patient risk determination for invasive aspergillosis including azole resistance. J. Hosp. Infect. 2018, 100, e91-e97. [CrossRef]

8. Prigitano, A.; Esposto, M.C.; Biffi, A.; De Lorenzis, G.; Favuzzi, V.; Koncan, R.; Lo Cascio, G.; Barao Ocampo, M.; Colombo, C.; Pizzamiglio, G.; et al. Triazole resistance in Aspergillus fumigatus isolates from patients with cystic fibrosis in Italy. J. Cyst. Fibros. 2017, 16, 64-569. [CrossRef]

9. Hagiwara, D.; Arai, T.; Takahashi, H.; Kusuya, Y.; Watanabe, A.; Kamei, K. Non-cyp51A azole-resistant Aspergillus fumigatus isolates with mutation in HMG-CoA reductase. Emerg. Infect. Dis. 2018, 24, 1889-1897. [CrossRef]

10. Zhang, J.; Snelders, E.; Zwaan, B.J.; Schoustra, S.E.; Meis, J.F.; van Dijk, K.; Hagen, F.; van der Beek, M.T.; Kampinga, G.A.; Zoll, J.; et al. A novel environmental azole resistance mutation in Aspergillus fumigatus and a possible role of sexual reproduction in its emergence. mBio 2017, 8, e00791-17. [CrossRef]

11. Prigitano, A.; Esposto, M.C.; Romanò, L.; Auxilia, F.; Tortorano, A.M. Azole-resistant Aspergillus fumigatus in the Italian environment. J. Glob. Antimicrob. Resist. 2019, 16, 220-224. [CrossRef] [PubMed]

12. Ashu, E.E.; Korfanty, G.A.; Samarasinghe, H.; Pum, N.; You, M.; Yamamura, D.; Xu, J. Widespread amphotericin B-resistant strains of Aspergillus fumigatus in Hamilton, Canada. Infect. Drug Resist. 2018, 11, 1549-1555. [CrossRef] [PubMed]

13. Hagiwara, D.; Miura, D.; Shimizu, K.; Paul, S.; Ohba, A.; Gonoi, T.; Watanabe, A.; Kamei, K.; Shintani, T.; Moye-Rowley, W.S.; et al. A novel Zn2 Cys6 transcription factor AtrR plays a key role in an azole resistance mechanism of Aspergillusfumigatus by co-regulating cyp51A and cdr1B expressions. PLoS Pathog. 2017, 13, e1006096. [CrossRef] [PubMed]

14. Sharma, C.; Nelson-Sathi, S.; Singh, A.; Pillai, M.R.; Chowdhary, A. Genomic perspective of triazole resistance in clinical and environmental Aspergillus fumigatus isolates without cyp51A mutations. Fungal Genet. Biol. 2019, 132. [CrossRef]

15. Lamoth, F.; Juvvadi, P.R.; Soderblom, E.J.; Moseley, M.A.; Asfaw, Y.G.; Steinbach, W.J. Identification of a key lysine residue in heat shock protein 90 required for azole and echinocandin resistance in Aspergillus fumigatus. Antimicrob. Agents Chemother. 2014, 58, 1889-1896. [CrossRef]

16. Beer, K.D.; Farnon, E.C.; Jain, S.; Jamerson, C.; Lineberger, S.; Miller, J.; Berkow, E.L.; Lockhart, S.R.; Chiller, T.; Jackson, B.R. Multidrug-resistant Aspergillus fumigatus carrying mutations linked to environmental fungicide exposure-Three states, 2010-2017. MMWR-Morb. Mortal. Wkly. Rep. 2018, 67, 1064-1067. [CrossRef]

17. Public Health England. English Surveillance Programme for Antimicrobial Utilization and Resistance (ESPAUR); Public Health England: London, UK, 2017; pp. 1-143.

18. Reichert-Lima, F.; Lyra, L.; Pontes, L.; Moretti, M.L.; Pham, C.D.; Lockhart, S.R.; Schreiber, A.Z. Surveillance for azoles resistance in Aspergillus spp. highlights a high number of amphotericin B-resistant isolates. Mycoses 2018, 61, 360-365. [CrossRef]

19. Mondol, M.A.; Shin, H.J. Antibacterial and antiyeast compounds from marine-derived bacteria. Mar. Drugs 2014, 12, 2913-2921. [CrossRef]

20. Matobole, R.; van Zyl, L.; Parker-Nance, S.; Davies-Coleman, M.; Trindade, M. Antibacterial activities of bacteria isolated from the marine sponges Isodictya compressa and Higginsia bidentifera collected from Algoa Bay, South Africa. Mar. Drugs 2017, 15, 47. [CrossRef] 
21. Kamarudheen, N.; Rao, K.V.B. Fatty acyl compounds from marine Streptomyces griseoincarnatus strain HK12 against two major bio-film forming nosocomial pathogens; an in vitro and in silico approach. Microb. Pathog. 2019, 127, 121-130. [CrossRef]

22. Mickymaray, S.; Alturaiki, W. Antifungal efficacy of marine macroalgae against fungal isolates from bronchial asthmatic cases. Molecules 2018, 23, 3032. [CrossRef] [PubMed]

23. Meng, L.; Sun, C.; Zhang, C.; Song, S.; Sun, X.; Ju, J.; Deng, Y. Efficacy of compounds isolated from Streptomyces olivaceus against the morphogenesis and virulence of Candida albicans. Mar. Drugs 2019, 17, 442. [CrossRef] [PubMed]

24. Sivakumar, K.C.; Sajeevan, T.P.; Bright Singh, I.S. Marine derived compounds as binders of the White spot syndrome virus VP28 envelope protein: In silico insights from molecular dynamics and binding free energy calculations. Comput. Biol. Chem. 2016, 64, 359-367. [CrossRef] [PubMed]

25. Jia, K.; Yuan, Y.; Liu, W.; Liu, L.; Qin, Q.; Yi, M. Identification of inhibitory compounds against Singapore grouper iridovirus infection by cell viability-based screening assay and droplet digital PCR. Mar. Biotechnol. 2017, 20, 35-44. [CrossRef] [PubMed]

26. Guo, P.; Li, G.; Liu, Y.; Lu, A.; Wang, Z.; Wang, Q. Naamines and naamidines as novel agents against a plant virus and phytopathogenic fungi. Mar. Drugs 2018, 16, 311. [CrossRef] [PubMed]

27. Melek, F.R.; Tadros, M.M.; Yousif, F.; Selim, M.A.; Hassan, M.H. Screening of marine extracts for schistosomicidal activity in vitro. Isolation of the triterpene glycosides echinosides A and B with potential activity from the sea cucumbers Actinopyga echinites and Holothuria polii. Pharm. Biol. 2012, 50, 490-496. [CrossRef]

28. Tasdemir, D.; MacIntosh, A.J.J.; Stergiou, P.; Kaiser, M.; Mansour, N.R.; Bickle, Q.; Huffman, M.A. Antiprotozoal and antihelminthic properties of plants ingested by wild Japanese macaques (Macaca fuscata yakui) in Yakushima Island. J. Ethnopharmacol. 2019, 247. [CrossRef]

29. Orhan, I.; Sener, B.; Kaiser, M.; Brun, R.; Tasdemir, D. Inhibitory activity of marine sponge-derived natural products against parasitic protozoa. Mar. Drugs 2010, 8, 47-58. [CrossRef]

30. Khanavi, M.; Toulabi, P.B.; Abai, M.R.; Sadati, N.; Hadjiakhoond, F.; Hadjiakhoondi, A.; Vatandoost, H. Larvicidal activity of marine algae, Sargassum swartzii and Chondria dasyphylla, against malaria vector Anopheles stephensi. J. Vector Dis. 2011, 48, 241-244.

31. Martins, L.F.; Mesquita, J.T.; Pinto, E.G.; Costa-Silva, T.A.; Borborema, S.E.T.; Galisteo Junior, A.J.; Galisteo Junior, A.J.; Neves, B.J.; Andrade, C.H.; Shuhaib, Z.A.; et al. Analogues of marine guanidine alkaloids are in vitro effective against Trypanosoma cruzi and selectively eliminate Leishmania (L.) infantum intracellular amastigotes. J. Nat. Prod. 2016, 79, 2202-2210. [CrossRef]

32. Peters, T.L.; Tillotson, J.; Yeomans, A.M.; Wilmore, S.C.; Lemm, E.; Jiménez-Romero, C.; Amador, L.A.; Li, L.; Amin, A.D.; Pongtornpipat, P.; et al. Target-based screening against eIF4A1 reveals the marine natural Product elatol as a novel inhibitor of translation initiation with in vivo antitumor activity. Clin. Cancer Res. 2018, 24, 4256-4270. [CrossRef] [PubMed]

33. Howarth, A.; Simms, C.; Kerai, N.; Allen, O.; Mihajluk, K.; Madureira, P.A.; Sokratous, G.; Cragg, S.; Lee, S.Y.; Morley, A.D.; et al. DIVERSet JAG compounds inhibit topoisomerase II and are effective against adult and pediatric high-grade gliomas. Transla. Oncol. 2019, 12, 1375-1385. [CrossRef] [PubMed]

34. Rath, B.; Hochmair, M.; Plangger, A.; Hamilton, G. Anticancer activity of fascaplysin against lung cancer cell and small cell lung cancer circulating tumor cell lines. Mar. Drugs 2018, 16, 383. [CrossRef] [PubMed]

35. Cowan, J.; Shadab, M.; Nadkarni, D.H.; Kc, K.; Velu, S.E.; Yusuf, N.A. Novel marine natural product derived pyrroloiminoquinone with potent activity against skin cancer cells. Mar. Drugs 2019, 17, 443. [CrossRef] [PubMed]

36. Wang, W.; Park, C.; Oh, E.; Sung, Y.; Lee, J.; Park, K.H.; Kang, H. Benzophenone compounds, from a marine-derived strain of the fungus Pestalotiopsis neglecta, inhibit proliferation of pancreatic cancer cells by targeting the MEK/ERK pathway. J. Nat. Prod. 2019, 82, 3357-3365. [CrossRef]

37. Oh, S.; Son, M.; Lee, H.S.; Kim, H.S.; Jeon, Y.J.; Byun, K. Protective effect of pyrogallol-phloroglucinol-6, 6-bieckol from Ecklonia cava on monocyte-associated vascular dysfunction. Mar. Drugs 2018, 16, 441. [CrossRef]

38. Chakraborty, K.; Antony, T. First report of spiro-compounds from marine macroalga Gracilaria salicornia: Prospective natural anti-inflammatory agents attenuate 5-lipoxygenase and cyclooxygenase-2. Nat. Prod. Res. 2019, 1-12. [CrossRef] [PubMed] 
39. Fernando, I.P.S.; Kim, M.; Son, K.-T.; Jeong, Y.; Jeon, Y.-J. Antioxidant activity of marine algal polyphenolic compounds: A mechanistic approach. J. Med. Food 2016, 19, 615-628. [CrossRef]

40. Nguyen, V.B.; Nguyen, T.H.; Doan, C.T.; Tran, T.N.; Nguyen, A.D.; Kuo, Y.-H.; Wang, S.-L. Production and bioactivity-guided isolation of antioxidants with $\alpha$-glucosidase inhibitory and anti-NO properties from marine chitinous materials. Molecules 2018, 23, 1124. [CrossRef]

41. Sun, Y.; Lin, Y.; Cao, X.; Xiang, L.; Qi, J. Sterols from Mytilidae show anti-aging and neuroprotective effects via anti-oxidative activity. Int. J. Mol. Sci. 2014, 15, 21660-21673. [CrossRef]

42. Prastya, M.E.; Astuti, R.I.; Batubara, I.; Takagi, H.; Wahyudi, A.T. Chemical screening identifies an extract from marine Pseudomonas sp.-PTR-08 as an anti-aging agent that promotes fission yeast longevity by modulating the Pap1-ctt1 ${ }^{+}$pathway and the cell cycle. Mol. Biol. Rep. 2019, 47, 33-43. [CrossRef] [PubMed]

43. Lauritano, C.; Ianora, A. Marine organisms with anti-diabetes properties. Mar. Drugs 2016, 14, 220. [CrossRef] [PubMed]

44. de Alencar Alves, M.F.; de Almeida Barreto, F.K.; de Vasconcelos, M.A.; do Nascimento Netro, L.G.; Carneiro, R.F.; Silva, L.T.D.; Nagano, C.S.; Sampaio, A.H.; Teixeira, E.H. Antihyperglycemic and antioxidant activities of a lectin from the marine red algae, Bryothamnion seaforthii, in rats with streptozotocin-induced diabetes. Int. J. Biol. Macromol. 2010, 158, 773-780. [CrossRef] [PubMed]

45. Nasab, B.S.; Homaei, A.; Pletschke, B.I.; Salinas-Solazar, C.; Castillo-Zacarias, C.; Parra-Saldívar, R. Marine resources effective in controlling and treating diabetes and its associated complications. Process. Biochem. 2020, 92, 313-342. [CrossRef]

46. Yu, J.; Proctor, R.H.; Brown, D.W.; Abe, K.; Gomi, K.; Machida, M.; Hasegawa, F.; Nierman, W.C.; Bhatnagar, D.; Cleveland, T.E. Genomics of economically significant Aspergillus and Fusarium species. In Applied Mycology and Biotechnology; Arora, D.K., Khachatourians, G.G., Eds.; Elsevier: Amsterdam, The Netherlands, 2004; pp. 249-283. [CrossRef]

47. Bennett, J.H. On the parasitic vegetable structures found growing in living animals. Trana. R. Soc. Edinb. 1844, 15, 277-294. [CrossRef]

48. Stevens, D.A.; Melikian, G.L. Aspergillosis in the 'nonimmunocompromised' host. Immunol. Investig. 2011, 40, 751-766. [CrossRef]

49. Siddiqui, A.A.; Shah, A.A.; Bashir, S.H. Craniocerebral aspergillosis of sinonasal origin in immunocompetent patients: Clinical spectrum and outcome in 25 cases. Neurosurgery 2004, 55, 602-613. [CrossRef]

50. Siddiqui, A.A.; Bashir, S.H.; Ali Shah, A.; Sajjad, Z.; Ahmed, N.; Jooma, R.; Enam, S.A. Diagnostic MR imaging features of craniocerebral aspergillosis of sino-nasal origin in immunocompetent patients. Acta Neurochir. 2006, 148, 155-166. [CrossRef]

51. Webb, B.J.; Vikram, H.R. Chronic invasive sinus aspergillosis in immunocompetent hosts: A geographic comparison. Mycopathologia 2010, 170, 403-410. [CrossRef]

52. Mody, K.H.; Ali, M.J.; Vemuganti, G.K.; Nalamada, S.; Naik, M.N.; Honavar, S.G. Orbital aspergillosis in immunocompetent patients. Br. J. Ophthalmol. 2014, 98, 1379-1384. [CrossRef]

53. Aggarwal, E.; Mulay, K.; Menon, V.; Sundar, G.; Honavar, S.G.; Sharma, M. Isolated orbital aspergillosis in immunocompetent patients: A multicenter study. Am. J. Ophthalmol. 2016, 165, 125-132. [CrossRef] [PubMed]

54. Baeesa, S.S.; Bakhaidar, M.; Ahamed, N.A.B.; Madani, T.A. Invasive orbital apex aspergillosis with mycotic aneurysm formation and subarachnoid hemorrhage in immunocompetent patients. World Neurosurg. 2017, 102, 42-48. [CrossRef] [PubMed]

55. Blaize, M.; Mayaux, J.; Nabet, C.; Lampros, A.; Marcelin, A.G.; Thellier, M.; Piarroux, R.; Demoule, A.; Fekkar, A. Fatal Invasive aspergillosis and coronavirus disease in an immunocompetent patient. Emerg. Infect. Dis. 2020, 26, 1636-1637. [CrossRef] [PubMed]

56. Bora, S.; Kumar, A.; Mishra, S.; Satyarthee, G.D.; Singh, P.K.; Sawarkar, D.; Verma, S.; Borkar, S.; Sharma, R.; Chandra, S.P.; et al. Intracranial aspergillosis amongst immunocompetent patients: An experience with combined surgical and medical management of 18 patients. Clin. Neurol. Neurosurg. 2019, 186, 105511. [CrossRef] [PubMed]

57. Ma, Y.; Li, W.; Ao, R.; Lan, X.; Li, Y.; Zhang, J.; Yu, S. Central nervous system aspergillosis in immunocompetent patients: Case series and literature review. Medicine 2020, 99, e22911. [CrossRef] 
58. Yoon, S.H.; Park, C.M.; Goo, J.M.; Lee, H.J. Pulmonary aspergillosis in immunocompetent patients without air-meniscus sign and underlying lung disease: CT findings and histopathologic features. Acta Radiol. 2011, 52, 756-761. [CrossRef] [PubMed]

59. Chen, L.; Han, X.; Li, Y.; Zhang, C.; Xing, X. Invasive pulmonary aspergillosis in immunocompetent patients hospitalised with influenza A-related pneumonia: A multicenter retrospective study. BMC Pulm Med. 2020, 20, 239. [CrossRef] [PubMed]

60. Chen, L.; Liu, Y.; Wang, W.; Liu, K. Adrenal and hepatic aspergillosis in an immunocompetent patient. Infect. Dis. 2015, 47, 428-432. [CrossRef]

61. Snelders, E.; Huisin't Veld, R.A.G.; Rijs, A.J.M.M.; Kema, G.H.J.; Melchers, W.J.G.; Verweij, P.E. Possible environmental origin of resistance of Aspergillus fumigatus to medical triazoles. Appl. Environ. Microb. 2009, 75, 4053-4057. [CrossRef]

62. Fang, W.; Latgé, J.P. Microbe profile: Aspergillus fumigatus: A saprotrophic and opportunistic fungal pathogen. Microbiology 2018, 164, 1009-1011. [CrossRef]

63. Vaezi, A.; Fakhim, H.; Javidnia, J.; Khodavaisy, S.; Abtahian, Z.; Vojoodi, M.; Nourbakhsh, F.; Badali, H. Pesticide behavior in paddy fields and development of azole-resistant Aspergillus fumigatus: Should we be concerned? J. Mycol. Med. 2018, 28, 59-64. [CrossRef] [PubMed]

64. Mohapatra, B.R.; Bapuji, M.; Sree, A. Antifungal efficacy of bacteria isolated from marine sedentary organisms. Folia Microbiol. 2002, 47, 51-55. [CrossRef] [PubMed]

65. Devi, P.; Wahidullah, S.; Rodrigues, C.; Souza, L.D. The sponge-associated bacterium Bacillus licheniformis SAB1: A source of antimicrobial compounds. Mar. Drugs 2010, 8, 1203-1212. [CrossRef] [PubMed]

66. Chen, H.; Cai, K.; Yao, R. A new macrolactam derivative from the marine actinomycete HF-11225. J. Antibiot. 2018, 71, 477-479. [CrossRef]

67. Santos, J.D.; Vitorino, I.; De la Cruz, M.; Díaz, C.; Cautain, B.; Annang, F.; Pérez-Moreno, G.; Gonzalez Martinez, I.; Tormo, J.R.; Martín, J.M.; et al. Bioactivities and extract dereplication of Actinomycetales isolated from marine sponges. Front. Microbiol. 2019, 10. [CrossRef]

68. Subramani, R.; Sipkema, D. Marine rare actinomycetes: A promising source of structurally diverse and unique novel natural products. Mar. Drugs 2019, 17, 249. [CrossRef]

69. Nagai, K.; Kamigiri, K.; Matsumoto, H.; Kawano, Y.; Yamaoka, M.; Shimoi, H.; Watanabe, M.; Suzuki, K. YM-202204, a new antifungal antibiotic produced by marine fungus Phoma sp. J. Antibiot. 2002, 55, 1036-1041. [CrossRef]

70. Orwa, P.; Mugambi, G.; Wekesa, V.; Mwirichia, R. Isolation of haloalkaliphilic fungi from Lake Magadi in Kenya. Heliyon 2020, 6, e02823. [CrossRef]

71. Al-Enazi, N.M.; Awaad, A.S.; Zain, M.E.; Alqasoumi, S.I. Antimicrobial, antioxidant and anticancer activities of Laurencia catarinensis, Laurencia majuscula and Padina pavonica extracts. Saudi Pharm. J. 2018, 26, 44-52. [CrossRef]

72. Al-Enazi, N.M.; Awaad, A.S.; Alqasoumi, S.I.; Alwethairi, M.F. Biological activities of the red algae Galaxaura rugosa and Liagora hawaiiana butters. Saudi Pharm. J. 2018, 26, 25-32. [CrossRef]

73. Silva, P.; Fernandes, C.; Barros, L.; Ferreira, I.C.F.R.; Pereira, L.; Gonçalves, T. The antifungal activity of extracts of Osmundea pinnatifida, an edible seaweed, indicates its usage as a safe environmental fungicide or as a food additive preventing post-harvest fungal food contamination. Food Funct. 2018, 9, 6187-6195. [CrossRef] [PubMed]

74. Martínez, K.A.; Lauritano, C.; Druka, D.; Romano, G.; Grohmann, T.; Jaspars, M.; Martín, J.; Díaz, C.; Cautain, B.; de la Cruz, M.; et al. Amphidinol 22, a new cytotoxic and antifungal amphidinol from the dinoflagellate Amphidinium carterae. Mar. Drugs 2019, 17, 385. [CrossRef] [PubMed]

75. Lakshmi, V.; Mishra, S.K.; Srivastava, S.; Chaturvedi, A.; Srivastava, M.N.; Shukla, P.K. Antifungal activity of marine sponge Haliclona exigua (Krikpatrick). J. Mycol. Méd. 2010, 20, 31-35. [CrossRef]

76. Xu, T.; Feng, Q.; Jacob, M.R.; Avula, B.; Mask, M.M.; Baerson, S.R.; Tripathi, S.K.; Mohammed, R.; Hamann, M.T.; Khan, I.A.; et al. The marine sponge-derived polyketide endoperoxide plakortide F acid mediates its antifungal activity by interfering with calcium homeostasis. Antimicrob. Agents Chemother. 2011, 55, 1611-1621. [CrossRef]

77. Zhang, X.; Jacob, M.R.; Rao, R.R.; Wang, Y.-H.; Agarwal, A.K.; Newman, D.J. Antifungal cyclic peptides from the marine sponge Microscleroderma herdmani. Res. Rep. Med. Chem. 2010, 22, 7-14. [CrossRef] 
78. Nazemi, M.; Alidoust Salimi, M.; Alidoust Salimi, P.; Motallebi, A.; Tamadoni Jahromi, S.; Ahmadzadeh, O. Antifungal and antibacterial activity of Haliclona sp. from the Persian Gulf, Iran. J. Mycol. Méd. 2014, 24, 220-224. [CrossRef]

79. Ismail, H.; Lemriss, S.; Aoun, B.Z.; Mhadhebi, L.; Dellai, A.; Kacem, Y.; Boiron, P.; Bouraoui, A. A activity of aqueous and methanolic extracts from the Mediterranean sea cucumber, Holothuria polii. J. Mycol. Méd. 2008, 18, 23-26. [CrossRef]

80. Yuan, W.-H.; Yi, Y.-H.; Tang, H.-F.; Liu, B.-S.; Wang, Z.-L.; Sun, G.-Q.; Zhang, W.; Li, L.; Sun, P. Antifungal triterpene glycosides from the sea cucumber Bohadschia marmorata. Planta Med. 2009, 75, 168-173. [CrossRef]

81. Yuan, W.-H.; Yi, Y.-H.; Tan, R.-X.; Wang, Z.-L.; Sun, G.-Q.; Xue, M.; Zhang, H.-W.; Tang, H.-F. Antifungal triterpene glycosides from the sea cucumber Holothuria (Microthele) axiloga. Planta Med. 2009, 75, 647-653. [CrossRef]

82. Barsby, T.; Kelly, M.T.; Andersen, R.J. Tupuseleiamides and basiliskamides, new acyldipeptides and antifungal polyketides produced in culture by a Bacillus laterosporus isolate obtained from a tropical marine habitat. J. Nat. Prod. 2002, 65, 1447-1451. [CrossRef]

83. Lacret, R.; Oves-Costales, D.; Gómez, C.; Díaz, C.; de la Cruz, M.; Pérez-Victoria, I.; Vicente, F.; Genilloud, O.; Reyes, F. New ikarugamycin derivatives with antifungal and antibacterial properties from Streptomyces zhaozhouensis. Mar. Drugs 2015, 13, 128-140. [CrossRef] [PubMed]

84. Lacret, R.; Pérez-Victoria, I.; Oves-Costales, D.; de la Cruz, M.; Domingo, E.; Martín, J.; Díaz, C.; Vicente, F.; Genilloud, O.; Reyes, F. MDN-0170, a new napyradiomycin from Streptomyces sp. strain CA-271078. Mar. Drugs 2016, 14, 188. [CrossRef] [PubMed]

85. Pérez-Victoria, I.; Oves-Costales, D.; Lacret, R.; Martín, J.; Sánchez-Hidalgo, M.; Diaz, C.; Cautain, B.; Vicente, F.; Genilloud, O.; Reyes, F. Structure elucidation and biosynthetic gene cluster analysis of caniferolides A-D, new bioactive glycosylated 36-membered polyol macrolides from the marine-derived Streptomyces caniferus CA-271066. Org. Biomol. Chem. 2019, 17. [CrossRef] [PubMed]

86. Kumar, S.; Kannabiran, K. Antifungal activity of Streptomyces VITSVK5 spp. against drug resistant Aspergillus clinical isolates from pulmonary tuberculosis patients. J. Mycol. Méd. 2010, 20, 101-107. [CrossRef]

87. Suthindhiran, K.; Kannabiran, K. Diversity and exploration of bioactive marine actinomycetes in the Bay of Bengal of the Puducherry coast of India. Indian J. Microbiol. 2010, 50, 76-82. [CrossRef]

88. Sata, N.U.; Matsunaga, S.; Fusetani, N.; van Soest, R.W.M. Aurantosides D, E, and F: New antifungal tetramic acid glycosides from the marine sponge Siliquariaspongia japonica. J. Nat. Prod. 1999, 62, 969-971. [CrossRef]

89. Edrada, R.A.; Ebel, R.; Supriyono, A.; Wray, V.; Schupp, P.; Steube, K.; van Soest, R.; Proksch, P. Swinhoeiamide A, a new highly active calyculin derivative from the marine sponge Theonella swinhoei. J. Nat. Prod. 2002, 65, 1168-1172. [CrossRef]

90. Chen, Y.; McCarthy, P.J.; Harmody, D.K.; Schimoler-O'Rourke, R.; Chilson, K.; Selitrennikoff, C.; Pomponi, S.A.; Wright, A.E. New bioactive peroxides from marine sponges of the family Plakiniidae. J. Nat. Prod. 2002, 65, 1509-1512. [CrossRef]

91. Sionov, E.; Roth, D.; Sandovsky-Losica, H.; Kashman, Y.; Rudi, A.; Chill, L.; Berdicevsky, I.; Segal, E. Antifungal effect and possible mode of activity of a compound from the marine sponge Dysidea herbacea. J. Infect. 2005, 50, 453-460. [CrossRef]

92. Pettit, G.R.; Chicacz, Z.A.; Gao, F.; Herald, C.L.; Boyd, M.R.; Schmidt, J.M.; Hooper, J.N.A. Antineoplastic agents. 257. Isolation and structure of spongistatin 1. J. Org. Chem. 1993, 58, 1302-1304. [CrossRef]

93. Pettit, R.K.; McAllister, S.C.; Pettit, G.R.; Herald, C.L.; Johnson, J.M.; Cichacz, Z.A. A broad-spectrum antifungal from the marine sponge Hyrtios erecta. Int. J. Antimicrob. Agents 1998, 9, 147-152. [CrossRef]

94. Oh, K.-B.; Lee, J.H.; Chung, S.-C.; Shin, J.; Shin, H.J.; Kim, H.-K.; Lee, H.-S. Antimicrobial activities of the bromophenols from the red alga Odonthalia corymbifera and some synthetic derivatives. Bioorg. Med. Chem. Lett. 2008, 18, 104-108. [CrossRef] [PubMed]

95. Alarif, W.M.; Al-Lihaibi, S.S.; Abdel-Lateff, A.; Ayya, S.-E.N. New antifungal cholestane and aldehyde derivatives from the red alga Laurencia papillosa. Nat. Prod. Commun. 2011, 6, 1821-1824. [CrossRef] [PubMed]

96. Kumar, R.; Chaturvedi, A.K.; Shukla, P.K.; Lakshmi, V. Antifungal activity in triterpene glycosides from the sea cucumber Actinopyga lecanora. Bioorg. Med. Chem. Lett. 2007, 17, 4387-4391. [CrossRef] 
97. Han, H.; Yi, Y.-H.; Li, L.; Liu, B.-S.; La, M.-P.; Zhang, H.-W. Antifungal active triterpene glycosides from sea cucumber Holothuria scabra. Acta Pharm. Sin. 2009, 44, 620-624.

98. Adibpour, N.; Nasr, F.; Nematpour, F.; Shakouri, A.; Ameri, A. Antibacterial and antifungal activity of Holothuria leucospilota isolated from Persian Gulf and Oman Sea. Jundishapur. J. Microb. 2014, 7, e8708. [CrossRef]

99. Lakshmi, V.; Srivastava, S.; Mishra, S.K.; Shukla, P.K. Antifungal activity of bivittoside-D from Bohadschia vitiensis (Semper). Nat. Prod. Res. 2012, 26, 913-918. [CrossRef]

100. Austin, B. The value of cultures to modern microbiology. Antonie Van Leeuwenhoek 2017, 110, 1247-1256. [CrossRef]

101. Pulschen, A.A.; Bendia, A.G.; Fricker, A.D.; Pellizari, V.H.; Galante, D.; Rodrigues, F. Isolation of uncultured bacteria from Antarctica using long incubation periods and low nutritional media. Front. Microbiol. 2017, 8. [CrossRef]

102. Bodor, A.; Bounedjoum, N.; Vincze, G.E.; Erdeiné Kis, Á.; Laczi, K.; Bende, G.; Szilágyi, Á.; Kovács, T.; Perei, K.; Rákhely, G. Challenges of unculturable bacteria: Environmental perspectives. Rev. Environ. Sci. Biotechnol. 2020, 19, 1-22. [CrossRef]

103. Kovalchuk, V.; Voronkina, A.; Binnewerg, B.; Schubert, M.; Muzychka, L.; Wysokowski, M.; Tsurkan, M.V.; Bechmann, N.; Petrenko, I.; Fursov, A.; et al. Naturally drug-loaded chitin: Isolation and applications. Mar. Drugs 2019, 17, 574. [CrossRef] [PubMed]

104. Rahman, M.A. Collagen of extracellular matrix from marine invertebrates and its medical applications. Mar. Drug 2019, 17, 118. [CrossRef] [PubMed]

105. Breger, J.; Fuchs, B.B.; Aperis, G.; Moy, T.I.; Asbel, F.M.; Mylonakis, E. Antifungal chemical compounds identified using a C. elegans pathogenicity assay. PLoS Pathog. 2007, 3, e18. [CrossRef] [PubMed]

106. Moy, T.I.; Conery, A.L.; Larkins-Ford, J.; Wu, G.; Mazitschek, R.; Casadei, G.; Lewis, K.; Carpenter, A.E.; Ausubel, F.M. High-throughput screen for novel antimicrobials using a whole animal infection model. ACS Chem. Biol. 2009, 4, 527-533. [CrossRef]

107. Graham, C.E.; Cruz, M.R.; Garsin, D.A.; Lorenz, M.C. Enterococcus faecalis bacteriocin EntV inhibits hyphal morphogenesis, biofilm formation, and virulence of Candida albicans. Proc. Natl. Acad. Sci. USA 2017, 25, 4507-4512. [CrossRef]

108. Manoharan, R.K.; Lee, J.H.; Kim, Y.G.; Kim, S.I.; Lee, J. Inhibitory effects of the essential oils $\alpha$-longipinene and linalool on biofilm formation and hyphal growth of Candida albicans. Biofouling 2017, 33, 143-155. [CrossRef]

109. Okoli, I.; Coleman, J.J.; Tempakakis, E.; An, W.F.; Holson, E.; Wagner, F.; Conery, A.L.; Larkins-Ford, J.; $\mathrm{Wu}, \mathrm{G} . ;$ Stern, A.; et al. Identification of antifungal compounds active against Candida albicans using an improved high-throughput Caenorhabditis elegans assay. PLoS ONE 2009, 4, e7025. [CrossRef]

110. Peterson, N.D.; Pukkila-Worley, R. Caenorhabditis elegans in high-throughput screens for anti-infective compounds. Curr. Opin. Immunol. 2018, 54, 59-65. [CrossRef]

111. Ahamefule, C.S.; Qin, Q.; Odiba, A.S.; Li, S.; Moneke, A.N.; Ogbonna, J.C.; Jin, C.; Wang, B.; Fang, W. Caenorhabditis elegans-based Aspergillus fumigatus infection model for evaluating pathogenicity and drug efficacy. Front. Cell. Infect. Microbiol. 2020, 10. [CrossRef]

112. Haferburg, G.; Groth, I.; Möllmann, U.; Kothe, E.; Sattler, I. Arousing sleeping genes: Shifts in secondary metabolism of metal tolerant actinobacteria under conditions of heavy metal stress. Biometals 2009, 22, 225-234. [CrossRef]

113. Morgenstern, A.; Paetz, C.; Behrend, A.; Spiteller, D. Divalent transition-metal-ion stress induces prodigiosin biosynthesis in Streptomyces coelicolor M145: Formation of coeligiosins. Chemistry 2015, 21, 6027-6032. [CrossRef] [PubMed]

114. Shi, Y.; Pan, C.; Auckloo, B.N.; Chen, X.; Chen, C.-T.A.; Wang, K.; Wu, X.; Ye, Y.; Wu, B. Stress-driven discovery of a cryptic antibiotic produced by Streptomyces sp. WU20 from Kueishantao hydrothermal vent with an integrated metabolomics strategy. Appl. Microbiol. Biotechnol. 2016, 101, 1395-1408. [CrossRef] [PubMed]

115. Hassan, S.S.; Shah, S.A.A.; Pan, C.; Fu, L.; Cao, X.; Shi, Y.; Wu, X.; Wang, K.; Wu, B. Production of an antibiotic enterocin from a marine actinobacteria strain $\mathrm{H} 1003$ by metal-stress technique with enhanced enrichment using response surface methodology. Pak. J. Pharm. Sci. 2017, 30, 313-324. [PubMed] 
116. Zhu, C.; Liu, X.; Chi, H.; Chen, C.; Chen, Z.; Fu, G.; Gong, H.; Huang, Y. System for the heterologous expression of NS1 protein of H9N2 avian influenza virus in the ciliate Tetrahymena thermophila. J. Vet. Med. Sci. 2018, 80, 1610-1618. [CrossRef]

Publisher's Note: MDPI stays neutral with regard to jurisdictional claims in published maps and institutional affiliations.

(C) 2020 by the authors. Licensee MDPI, Basel, Switzerland. This article is an open access article distributed under the terms and conditions of the Creative Commons Attribution (CC BY) license (http://creativecommons.org/licenses/by/4.0/). 